\title{
KEMAMPUAN BERPIKIR KRITIS MELALUI PEMBELAJARAN MATEMATIKA DENGAN PROBLEM BASED LEARNING
}

\author{
Berta Apriza ${ }^{1}$ \\ ${ }^{1}$ Program Studi Pendidikan Guru Sekolah Dasar STKIP Muhammadiyah Kotabumi \\ email: berthaafriza90@gmail.com
}

\begin{abstract}
Education functions to upgrading, forming, character and develop civilization nation. Having the ability to think and actions to effective and creative in the realm of abstract and concrete can be used as self development independently. Students need to armed with critical thinking skills, systematic, logical, creative, and cooperate effectively to obtain, choose, and manage an information. Mathematics learning is directed to develop critical thinking skills and discussed open and objective because mathematics having strong and structure clear and links between the concept of the one with another concept. By analyzing learning needs of mathematics, formulate and designed a learning programs, choose a strategies and evaliated them correctly to get good results. The ability critical thinking is very important in studying new matter and that known way, and learn to ask effectively and reach a conclusion consistent with the facts. Mathematic learning with problem based learning is the concept of better used activity of the student during learning. In accordance with statements from Westwood (2008: 31) stated that PBL: 1) propel oneself directly in learning, 2) prepared students to critical thinking and analytical, 3) give opportunity to students to identify, find and use numerous this approuch in should think, 4) is the learning is very closely related to the real world and motivate students, 5) involving activeness in integrating information and skills of various the discipline, and 6) knowledge and strategy by the possibility of will be maintained and tranferred to the learning situation other, improve the ability to communicate and the social skills needed to cooperation and teamwork. By chance the learning process as an alternative in solving mathematical problems with using the ability critical think an to cultivate the scientific attitude of student.
\end{abstract}

Keywords: The Ability Critical Thinking, Mathematic Learning, Problem Based Learning

\section{PENDAHULUAN}

Berpikir merupakan sebuah aktivitas yang dilakukan manusia bahkan saat keadaan tertidur. Bagi otak, berpikir dan menyelesaikan masalah merupakan paling penting dengan kemampuan yang tidak terbatas. Kemampuan berpikir adalah salah satu kecakapan hidup (life skill) yang perlu dikembangkan melalui proses pendidikan.
Sejalan dengan pendapat Bassham, Irwin, Nardone, and Wallace (2011:1) mengungkapkan bahwa fungsi pendidikan adalah mengajarkan seseorang untuk berpikir secara intensif dan berpikir kritis. Orangorang yang memiliki kemampuan berpikir kritis tidak hanya mengenal sebuah jawaban. Namun, akan terus mencoba mengembangkan kemungkinan jawaban lain- 
nya berdasarkan analisis, proses penalaran sampai pada tahap kompleks, dan informasi yang telah didapat dari suatu permasalahannya.

Matematika merupakan ilmu universal yang berguna bagi kehidupan manusia dan juga mendasari perkembangan teknologi modern, serta mempunyai peran penting dalam berbagai disiplin ilmu dan memajukan daya pikir manusia. Dalam kurikulum 2013 dinyatakan bahwa mata pelajaran matematika perlu diberikan kepada semua peserta didik mulai dari sekolah dasar hingga sekolah menengah untuk membekali peserta didik dengan kemampuan berpikir logis, analitis, sistematis, kritis, inovatif dan kreatif, serta kemampuan bekerja sama. Pembelajaran matematika melatih cara berpikir dan bernalar dalam menarik kesimpulan, misalnya melalui kegiatan penyelidikan, eksplorasi, eksperimen, menunjukkan kesamaan, perbedaan, konsisten, dan inkonsistensi. Smith (Chambers, 2013:7) menyatakan "value of learning mathematics as being something that 'discipline the mind, develops logical and critical reasoning, and develops analytical and problem solving skills to a high degree', which is a more helpful articulation of the purist standpoint". Dari pernyataan tersebut dapat dipahami bahwa nilai yang terkandung dalam pembelajaran matematika dapat membantu peserta didik dalam mendisiplinkan akal, meningkatkan kemampuan berpikir kritis dan logis, dan meningkatkan kemampuan analisis dan pemecahan masalah tingkat tinggi.

Partisipasi yang baik dalam pembelajaran dapat dilihat dari fakta-fakta akan keterampilan dan kemampuan berpikir serta kompetensi peserta didik pada saat bekerja sama. Hal ini memberikan kesempatan kepada peserta didik untuk membangun pengetahuannya secara aktif. Artinya pengetahuan ditemukan, dibentuk, dan dikembangkan sendiri serta peserta didik belajar berdasarkan masalah yang terkait dengan dunia nyata sehingga pembelajaran lebih bermakna bagi mereka. Problem Based Learning (PBL) menawarkan keterlibatan peserta didik secara aktif dalam proses pembelajaran.

Panen (dalam Rusmono, 2012:74) mengatakan bahwa dalam pembelajaran PBL, peserta didik terlibat dalam proses penelitian yang mengharuskannya untuk mengidentifikasi permasalahan, mengumpulkan data, dan menggunakan data tersebut untuk pemecahan masalah. Penerapan PBL dalam pembelajaran dapat menstimulus peserta didik untuk menggunakan kemampuan berpikir, meningkatkan kemampuan matematik siswa, mengoptimalkan penguasaan materi belajar, menerapkan belajar dalam kelompok, dan dapat memaknai pembelajaran dengan baik.

Berdasarkan pemikiran di atas, tulisan ini dimaksudkan untuk memberikan 
dasar-dasar kemampuan berpikir kritis dalam pembelajaran matematika dengan problem based learning sehingga penguasaan materi belajar dan penyelesaian masalah dalam matematika yang berkaitan meningkat dengan baik.

\section{PEMBAHASAN}

\section{Kemampuan Berpkir Kritis}

Kemampuan berpikir kritis setiap individu berbeda antara satu dengan lainnya sehingga perlu dipupuk sejak dini. Berpikir terjadi dalam setiap aktivitas manusia yang berfungsi untuk menyelesaikan masalah, membuat keputusan, serta mencari alasan. Proses atau jalannya berpikir memiliki tiga langkah pokok, yaitu: (1) pembentukan pengertian, (2) pembentukan pendapat, dan (3) penarikan kesimpulan. Mason berpendapat (2008:2) bahwa berpikir kritis didasari oleh keterampilan yang khusus, seperti kemampuan untuk menilai alasan benar, atau untuk menimbang bukti yang relevan, atau untuk mengidentifikasi argumen menyesatkan (keliru). Seseorang yang berpikir kritis memiliki karakter khusus yang dapat diidentifikasi dengan melihat bagaimana seseorang menyikapi suatu masalah, kebiasaan dalam bertindak, berargumen, dan memanfaatkan intelektualnya serta pengetahuannya.

Paul, R. dan Elder, L (2008:2) menyatakan bahwa berpikir kritis adalah bentuk menganalisis dan mengevaluasi dalam berpikir dengan maksud untuk meningkatkannya satu sama lain, serta dapat membentuk pemikiran korektif pendek, mandiri, dan disiplin diri. Hal ini membutuhkan standar yang ketat dari keunggulannya dan perintah sadar dalam penggunaannya. Mempunyai makna sama dengan pendapat Glazer (2001:1) bahwa:

"critical thinking in mathematics is the ability and disposition to incorporate prior knowledge, mathematical reasoning, and cognitive strategies to generalize, prove, or evaluate unfamiliar mathematical situations in a reflective manner.

Maksudnya adalah berpikir kritis dalam matematika merupakan kemampuan dan disposisi untuk menggabungkan pengetahuan, penalaran matematika, dan strategi kognitif untuk menggeneralisasi, membuktikan, atau mengevaluasi situasi matematis secara efektif. Indikator dari keterampilan berpikir kritis ada lima perlakuan yang sistematis, yaitu:

\section{a. Berpikir Kritis Sebagai Keterampilan Menganalisis}

Jika seorang peserta didik memiliki pengetahuan yang memadai (prior Knowledge), ia dapat membangun atau membentuk kerangka berpikirnya sendiri untuk mempertanyakan dan menilai informasi atau pengetahuan baru yang diperolehnya.

\section{b. Berpikir kritis dalam Mensintesis}

Peserta didik seringkali menjadi penerima informasi yang pasif dari setiap informasi 
yang didapatkan, baik itu dengan cara mendengar maupun melihat, hendaknya peserta didik terbiasa untuk tidak mudah menarik sebuah kesimpulan dan mengambil keputusan atas apa yang mereka dapatkan.

\section{c. Berpikir kritis dalam Mengenal dan Menyelesaikan Masalah}

Proses berpikir memerlukan banyak langkah dan strategi yang dilakukan tidak hanya dengan mengikuti cara dan langkah yang sudah ada dan tersedia dalam pikiran sendiri.

\section{d. Berpikir kritis dalam Menyimpulkan dan Mengambil Keputusan}

Dalam mengambil keputusan atas setiap masalah yang dihadapi, dibutuhkan kemampuan yang baik dalam menganalisis, mengeneralisasikan, mengorganisasikan, membandingkan, mengevalusai, dan membuat kesimpulan dari masalah yang dihadapi.

\section{e. Keterampilan dalam Mengevaluasi dan Menilai}

Dalam taksonomi Bloom, keterampilan mengevaluasi merupakan tahap kognitif yang paling tinggi, karena pada tahap ini peserta didik dituntut untuk mampu menyinergikan aspek-aspek kognitif lainnya dalam menilai sebuah fakta atau konsep.
Berikut adalah gambar yang berbentuk piramid dari pengetahuan kognitif (Taksonimi Bloom).

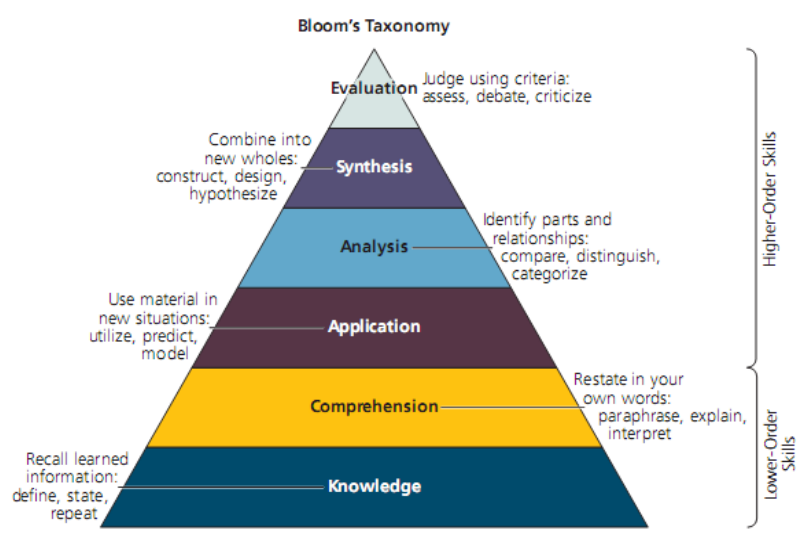

Gambar. 1

Kegiatan kognitif (Taksonomi Bloom) Jackson, D \& Newberry, P (2012: 3)

Kemampuan berpikir kritis dapat mendorong peserta didik memunculkan ideide atau pemikiran baru, menyeleksi berbagai pendapat sehingga dapat membedakan mana pendapat yang relevan ataupun yang tidak relevan. Sejalan dengan pendapat Ryan (2015:2) yang menyatakan bahwa berpikir kritis dapat membantu menafsirkan ide-ide yang kompleks, menilai bukti yang disediakan untuk mendukung argumen, dan membedakan antara kewajaran dan tidak masuk akal. Berpikir kritis adalah keterampilan dalam mengajukan pertanyaan yang relevan. Kemampuan dan indikator berpikir kritis lebih lanjut diuraikan pada tabel berikut. 
Tabel 2

Kemampuan dan Indikator berpikir kritis

\begin{tabular}{|c|l|l|}
\hline No & $\begin{array}{l}\text { Kemampuan } \\
\text { Berpikir } \\
\text { Kritis }\end{array}$ & \multicolumn{1}{|c|}{ Indikator } \\
\hline 1 & $\begin{array}{l}\text { Memberikan } \\
\text { argument }\end{array}$ & $\begin{array}{l}\text { Argumen dengan alasan; } \\
\text { menunjukan perbedaan } \\
\text { dan persamaan; serta } \\
\text { argumen yang utuh. }\end{array}$ \\
\hline 2 & $\begin{array}{l}\text { Melakukan } \\
\text { deduksi }\end{array}$ & $\begin{array}{l}\text { Mendeduksikan secara } \\
\text { logis, kondisi logis, serta } \\
\text { melakukan interpretasi } \\
\text { terhadap pernyataan. }\end{array}$ \\
\hline 3 & $\begin{array}{l}\text { Melakukan } \\
\text { induksi }\end{array}$ & $\begin{array}{l}\text { Melakukan pengumpul- } \\
\text { an data; membuat gene- } \\
\text { ralisasi dari data; mem- } \\
\text { buat tabel dan grafik. }\end{array}$ \\
\hline 4 & $\begin{array}{l}\text { Melakukan } \\
\text { evaluasi }\end{array}$ & $\begin{array}{l}\text { dasarkan fakta, berdasar- } \\
\text { kan pedoman atau } \\
\text { prinsip serta memberi- } \\
\text { kan alternatif. }\end{array}$ \\
\hline 5 & $\begin{array}{l}\text { Memilih kemungkinan } \\
\text { dan } \\
\text { melusi dan menentukan } \\
\text { kemungkinan-kemung- } \\
\text { kinan yang akan di- } \\
\text { laksanakan. }\end{array}$ \\
\hline
\end{tabular}

\section{Pembelajaran Matematika}

Kemampuan manusia untuk belajar merupakan karakteristik yang membedakan dirinya dengan makhluk hidup lain. Belajar sangat bermanfaat bagi setiap orang. Seseorang yang selalu belajar akan terus menerus mengembangkan potensi yang dimilikinya dan berimbas pada peningkatan kualitas hidupnya. Matematika merupakan ilmu yang universal dan perlu diberikan kepada semua peserta didik mulai dari sekolah dasar untuk membekali peserta didik dengan kemampuan berpikir logis, analitis, sistematis, kritis, dan kreatif, serta kemampuan bekerja sama. Selain itu matematika sekolah bertujuan untuk mengembangkan kemampuan menggunakan matematika dalam pemecahan masalah dan mengomunikasikan idea tau gagasan dengan menggunakan simbol, tabel, diagram, dan media lain.

Proses pembelajaran di kelas sebagai implementasi dari sebuah kurikulum merupakan sarana untuk membantu peserta didik memperoleh informasi, ide, keterampilan, nilai, cara berpikir, mengekspresikan diri, dan cara-cara bagaimana untuk belajar. Pembelajaran matematika dasarnya bertujuan dalam tercapainya keberhasilan mahasiswa dalam mempelajari matematika. Nitko dan Brokhart (2011:20) menyatakan bahwa "instruction is the process you see to provide students with the conditions that help them achieve the learning targets". Maksudnya adalah pembelajaran merupakan proses yang digunakan untuk memberikan peserta didik suatu kondisi yang membantu mereka untuk mencapai target belajar. Dalam hal ini target belajar berkaitan dengan hasil (output) yang diperoleh peserta didik setelah memperoleh proses pembelajaran. Keberhasilan atau target tersebut tidak hanya meningkatnya prestasi belajar, tetapi yang lebih penting meningkatnya kompetensi-kompetensi seperti kemampuan berpikir kritis peserta didik.

Dalam Permendikbud Nomor 58 tahun 2013, disebutkan bahwa tujuan pembelajaran matematika di sekolah pada 
tingkat lanjut, yaitu agar peserta didik memiliki kemampuan sebagai berikut:

1. Memahami konsep matematika, merupakan kompetensi dalam menjelaskan keterkaitan antarkonsep dan menggunakan konsep maupun algoritma, secara luwes, akurat, efisien, dan tepat, dalam pemecahan masalah.

2. Menggunakan pola sebagai dugaan dalam penyelesaian masalah dan mampu membuat generalisasi berdasarkan fenomena atau data yang ada. Menggunakan pola sebagai dugaan dalam penyelesaian masalah, dan mampu membuat generalisasi berdasarkan fenomena atau data yang ada.

3. Menggunakan penalaran pada sifat, melakukan manipulasi matematika baik dalam penyederhanaan, maupun menganalisis komponen yang ada dalam pemecahan masalah dalam konteks matematika maupun di luar matematika (kehidupan nyata, ilmu, dan teknologi). Hal ini meliputi kemampuan memahami masalah, membangun model matematika, menyelesaikan model dan menafsirkan solusi yang diperoleh termasuk dalam rangka memecahkan masalah dalam kehidupan sehari-hari (dunia nyata).

4. Mengomunikasikan gagasan, penalaran serta mampu menyusun bukti matematika dengan menggunakan kalimat lengkap, simbol, tabel, diagram, atau media lain untuk memperjelas keadaan atau masalah.

5. Memiliki sikap menghargai kegunaan matematika dalam kehidupan, yaitu memiliki rasa ingin tahu, perhatian, dan minat dalam mempelajari matematika, serta sikap ulet dan percaya diri dalam pemecahan masalah.

6. Memiliki sikap dan perilaku yang sesuai dengan nilai-nilai dalam matematika dan pembelajarannya, seperti taat azas, konsisten, menjunjung tinggi kesepakatan, toleran, menghargai pendapat orang lain, santun, demokrasi, ulet, tangguh, kreatif, menghargai kesemestaan (konteks, lingkungan), kerjasama, adil, jujur, teliti, cermat, bersikap luwes dan terbuka, memiliki kemauan berbagi rasa dengan orang lain.

7. Melakukan kegiatan-kegiatan motorik yang menggunakan pengetahuan matematika.

8. Menggunakan alat peraga sederhana maupun hasil teknologi untuk melakukan kegiatan-kegiatan matematika. Kecakapan atau kemampuankemampuan tersebut saling terkait erat, yang satu memperkuat sekaligus membutuhkan yang lain.

Sumarno (2010) menyatakan bahwa pembelajaran matematika diarahkan untuk 
mengembangkan (1) kemampuan berpikir matematis yang meliputi: pemahaman, pemecahan masalah,penalaran, komunikasi, dan koneksi matematis; (2) kemampuan berfikir kritis, serta sikap yang terbuka dan obyektif, serta (3) disposisi matematis atau kebiasaan, dan sikap belajar berkualitas yang tinggi. Kebiasaan dan sikap belajar yang dimaksud antara lain terlukis pada karakteristik utama SRL yaitu: (1) Menganalisis kebutuhan belajar matematika, merumuskan tujuan; dan merancang program belajar (2) Memilih dan menerapkan strategi belajar; (3) Memantau dan mengevaluasi diri apakah strategi telah dilaksanakan dengan benar, memeriksa hasil (proses dan produk), serta merefleksi untuk memperoleh umpan balik. Hal yang serupa dengan apa yang diungkapkan Joyce, et al. (2009:7) pengajaran yang baik adalah pengajaran yang merangkul pengalaman belajar tanpa batas mengenai bagaimana gagasan dan emosi berinteraksi dengan suasana kelas dan bagaimana keduanya dapat berubah sesuai suasana yang juga turut berubah.

Pembelajaran matematika juga harus mencerminkan bagaimana pengguna matematika menyelidiki situasi masalah, menentukan variable-variabel, melakukan perhitungan, dan memverifikasi kebenaran prediksi tersebut. Secara umum dinyatakan dalam NCTM (2000:16), "effective mathematics teaching requires under- standing what students know and need to learn and then challenging and supporting them to learn it well". Makna dari pernyataan tersebut adalah bahwa pembelajaran matematika yang efektif membutuhkan pemahaman tentang apa yang peserta didik tahu dan butuhkan untuk dipelajari, kemudian menantang dan mendukung mereka mempelajarinya dengan baik. Dengan adanya pembelajaran matematika yang seperti ini, maka akan dapat dipastikan untuk melakukan penilaian terhadap apa yang telah siswa pelajari selama proses pembelajaran.

\section{Problem Based Learning}

Pembelajaran dengan PBL memberikan kesempatan kepada siswa untuk mempelajari materi akademis dan keterampilan mengatasi masalah dengan terlibat di berbagai situasi kehidupan nyata. Problem Based Learning merupakan pembelajaran yang menjadikan masalah sebagai dasar atau basis bagi siswa untuk belajar. Uden \& Beaumont (2006:29) menyatakan "Unlike conventional learning, PBL takes an integrated approach to learning based on the requirements of the problem as perceived by the learners". Dari pernyataan tersebut dapat dipahami bahwa tidak seperti belajar secara konvensional, PBL menggunakan pendekatan terintegrasi dalam belajar yang mensyaratkan adanya masalah yang dapat dirasakan oleh pelajar. 
Seperti halnya yang diungkapkan Weissinger (2004: 46) menyatakan "Problem Based Learning (PBL) is an instructional strategy that encourages students to develop critical thinking and problem-solving skills that they can carry with them throughout their lifetimes". Maksudnya bahwa belajar berbasis masalah merupakan suatu strategi pembelajaran yang mendorong siswa untuk mengembangkan kemampuan berpikir kritis dan dapat menyelesaikan masalah yang dapat digunakan mereka sepanjang hidupnya

Adapun karakteristik yang dimiliki oleh PBL menurut Arends (2012:397) yakni sebagai berikut:

a. Pernyataan atau masalah perangsang. PBL mengorganisasikan pengajaran diseputar pertanyaan dan masalah yang penting secara social dan bermakna secara personal bagi siswa. Peserta didik dihadapkan pada berbagai situasi kehidupan nyata dan ada berbagai solusi yang competing untuk menyelesaikannya.

b. Focus interdisipliner. Meskipun PBL dapat dipusatkan pada subjek tertentu (sains, matematika, dan sejarah), tetapi masalah yang diinvestigasikan dipilih karena solusinya menuntut peserta didik untuk menggali banyak subjek.

c. Investigasi autentik. PBL mengharuskan peserta didik untuk melakukan investigasi autentik yang berusaha menemukan solusi riil untuk masalah riil. Peserta didik harus menganalisis dan menetapkan masalahnya, mengembangkan hipotesis dan membuat prediksi, mengumpulkan dan menganalisis informasi, melaksanakan eksperimen (jika memungkinkan), membuat inferensi, dan menarik kesimpulan. Metode investigasif yang digunakan tentu bergantung pada masalah yang diteliti.

d. Produksi artefak dan exhibit. PBL menuntut peserta didik untuk mengkonstruksikan produk dalam berbagai artefak dan exhibit yang menjelaskan atau merepresentasikan solusi mereka. Salah satu diantaranya yaitu penyusunan permasalahan secara bertahap, siswa membuat model permasalahan yang didapat saat proses pembelajaran kemudian siswa membangun program untuk penyelesaian dari permasalahan yang didapat, hingga pada akhirnya peserta didik mempresentasikan hasil yang dipelajari.

e. Kolaborasi. PBL ditandai oleh peserta didik yang bekerja bersama peserta didik lain secara berpasangan ataupun dalam kelompok kecil. Bekerjaa bersama memberikan motivasi untuk keterlibatan secara berkelanjutan dalam tugas-tugas kompleks dan meningkatkan kesempatan untuk melakukan penyelidikan dan dialog bersama serta 
mengembangkan berbagai keterampilan sosial.

Pendapat serupa juga diungkapkan oleh Cheong (2008:47) bahwa,

in the traditional teacher-centered approach, the teacher is knowledgeable in the subject matter and the focus of teaching is on the transmission of knowledge from the expert teacher to the novice student. In contrast, the PBL approach is a student-centered approach in which the focus is on student's learning and what they do to achieve this. In such an environment, the role of the teacher is more of a facilitator than an instructor.

Pada pembelajaran tradisional yang berpusat pada guru, guru sebagai sumber pengetahuan pada materi pelajaran dan fokus pengajaran sebagai proses pemindahan pengetahuan dari guru pada peserta didik. Sebaliknya, pada pembelajaran PBL, pembelajaran dipusatkan kepada peserta didik sementara guru lebih berperan sebagai fasilitator dan instruktur.

Menurut Eggen \& Kauchak (2012:311), tahapan-tahapan dalam pembelajaran PBL adalah sebagai berikut.

\section{Tabel 2}

\section{Fase PBL}

\begin{tabular}{|l|l|}
\hline \multicolumn{1}{|c|}{ Tahap } & \multicolumn{1}{|c|}{ Deskripsi } \\
\hline $\begin{array}{l}\text { Fase 1: Mereview dan } \\
\text { menyajikan masalah. }\end{array}$ & - Menarik perhaitan \\
Guru mereview pengetahuan & lajaran \\
yang dibutuhkan untuk me- & - Memberikan fo- \\
mecahkan masalah dan mem- & kus konkret untuk \\
berikan siswa masalah untuk & pelajaran \\
dipecahkan & \\
\hline
\end{tabular}

\begin{tabular}{|c|c|}
\hline $\mathbf{p}$ & $\overline{D e}$ \\
\hline $\begin{array}{l}\text { Fase 2: Menyusun strategi. } \\
\text { Siswa menyusun strategi } \\
\text { untuk memecahkan masalah } \\
\text { dan guru memberikan mereka } \\
\text { umpan balik soal strategi } \\
\text { tersebut }\end{array}$ & $\begin{array}{l}\text { Memastikan sebisa } \\
\text { mungkin bahwa sis- } \\
\text { wa menggunakan } \\
\text { pendekatan yang } \\
\text { berguna untuk me- } \\
\text { mecahkan masalah }\end{array}$ \\
\hline $\begin{array}{l}\text { Fase 3: Menerapkan } \\
\text { strategi. } \\
\text { Siswa menerapkan strategi- } \\
\text { strategi mereka saat guru } \\
\text { secara cermat memonitor } \\
\text { upaya mereka dan mem- } \\
\text { berikan umpan balik }\end{array}$ & $\begin{array}{l}\text { Memberi siswa pe- } \\
\text { ngalaman untuk me- } \\
\text { mecahkan masalah }\end{array}$ \\
\hline $\begin{array}{l}\text { Fase 4: Membahas dan } \\
\text { mengevaluasi hasil. } \\
\text { Guru membimbing diskusi } \\
\text { tentang upaya siswa dan hasil } \\
\text { yang mereka dapatkan }\end{array}$ & $\begin{array}{l}\text { Memberi siswa um- } \\
\text { pan balik tentang } \\
\text { upaya mereka }\end{array}$ \\
\hline
\end{tabular}

Manfaat lain yang didapat dengan menerapkan Pembelajaran PBL menurut Westwood (2008:31), yaitu 1) mendorong diri sendiri secara langsung dalam belajar (encourages self-direction in learning), 2) menyiapkan siswa untuk berpikir secara kritis dan analitis (prepares students to think critically and analytically), 3) memberikan kesempatan kepada siswa untuk mengidentifikasi, menemukan dan menggunakan berbagai pendekatan dalam berpikir (empowers students to identify, locate and use appropriate resources), 4) masalah belajar sangat erat kaitannya dengan dunia nyata dan memotivasi siswa (issues studied are linked closely with the 
real world and are motivating for students),

5) melibatkan keaktifan dalam mengintegrasikan informasi dan keterampilan dari berbagai disiplin ilmu (active involvement in integrating information and skills from different disciplines), dan 6) pengetahuan dan strategi yang diperoleh kemungkinan akan dipertahankan dan dipindahkan ke situasi belajar lainnya, meningkatkan kemampuan komunikasi dan keterampilan sosial yang diperlukan untuk kerja sama dan kerja sama tim (knowledge and strategies acquired are likely to be retained and transferred to other learning situations enhances communication skills and social skills necessary for cooperation and teamwork.)

\section{Kemampuan Berpikir Kritis dalam Pembelajaran Matematika dengan Problem Based Learning}

Kemampuan berpikir kritis merupakan proses kognitif yang terarah, jelas, dan aktif pada peserta didik sehingga dapat mendisiplinkan intelektualnya dalam memecahkan masalah, menganalisis, membuat kesimpulan, dan mengevaluasi semua aspek dari situasi masalah matematika yang diberikan. Dalam proses pembelajaran matematika dengan Problem Based Learning, peserta didik dihadapkan dengan permasalahan yang riil dalam matematika yang kemudian dibimbing agar mereka dapat mengindentifikasi, menganalisis, serta mengevaluasi masalah tersebut. Dengan demikian, proses pembelajaran ini dapat menjadi filter bagi peserta didik dalam membedakan masalah yang relevan dan tidak relevan, yang dapat membantu peserta didik dalam membuat pertimbangan dalam sebuah keputusan. Selain itu, dapat meyakinkan mereka dalam melakukan sebuah tindakan, atau berpikir kritis sehingga dapat dikatakan sebagai kompetensi yang akan dicapai serta alat yang digunakan dalam mengonstruksi pengetahuannya. Pada tahap ini harapannya peserta didik dapat menggunakan keterampilan sosial, pengetahuan, dan strategi untuk menyelesaikan masalah dengan cara sendiri.

Dengan kerja sama tim, peserta didik diberi kesempatan untuk melakukan diskusi dengan temannya kemudian mengarahkannya untuk mengambil kesimpulan dari hasil diskusi tersebut. Dengan melakukan beberapa langkah dalam menyelesaikan permasalahan matematika maka kemampuan berpikir kritis peserta didik dalam pembelajaran matematika dengan Problem Based Laerning yang didapatkan optimal sesuai dengan indikatorindikatornya.

\section{PENUTUP}

Pembelajaran matematika dengan problem based learning memberikan 
pengaruh positif dalam mengembangkan kemampuan berpikir kritis. Melalui problem based learning dalam pembelajaran matematika yang disajikan dalam bentuk masalah matematika, peserta didik diberi kesempatan untuk mengidentifikasi, menganalisis, serta mengevaluasi masalah dengan menggunakan kemampuan berpikir kritis yang baik sesuai dengan indikatornya. Tenaga pendidik disarankan untuk memberikan informasi dan bimbingan tentang bagaimana pembelajaran matematika dengan problem based laerning yang membuahkan kemampuan berpikir kritis meningkat dengan baik.

\section{DAFTAR RUJUKAN}

Arends, R. I. 2012. Learning to teach. $\left(9^{\text {th }}\right.$ ed). New York: McGraw-Hill Companies, Inc.

Basham, Irwin, Nardone, and Wallace. 2011. Critical thingking a student's introduction. New York, NY: McGraw-Hill

Chambers, P. 2013. Teaching mathematics: developing as a reflektive secondary teacher. $\left(2^{\text {th }}\right.$ ed). London: Sage Publication inc.

Cheong, F. 2008. Using a problem based learning approach teach an intelligent system course. [versi Elektronic]. Journal of information technology education, Volume 7, Page 47-60 .

Eggen. P. \& Kauchak. D. 2012. Strategi dan model pembelajaran. (Terjemahan Satrio Wahono). Jakarta: Indeks.

Glazer, E. 2001. Using internet primary sources to teach critical thinking skills in mathematics. Westport, CA: British Library

Jackson, D., \& Newberry, P. 2012. Critical thingking a user's manual. Boston, MA: Wadsworth

Joyce, Bruce, Weil, \& Cahoun. 2009. Models of teaching. model-model pengajaran. Yogyakarta: Pustaka Pelajar

Mason, M. 2008. Critical thingking and learning. Victoria: Blackwell Publishing

Mendikbud. 2013. Peraturan Menteri Pendidikan dan Kebudayaan Nomor 58, Tahun 2013, tentang Kurikulum 2013 Sekolah Menengah Pertama/Madrasah Tsanawiyah.

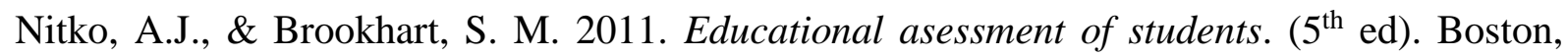
Massachusetts: Pearson Educational.

NCTM. 2000. Principles and standars for school mathematics. New York, NY: The National Council of Teachers of Mathematics, Inc. 
Paul, R., \& Elder, L. 2008. The miniature guide to critical thinking concepts and tools. California: Santa Rosa.

Rusmono. 2012. Strategi pembelajaran dengan problem based learning itu perlu. Bogor: Ghalia Indonesia.

Ryan, V. R. 2015. Beyon feelings a guide to critical thinking. Diambil tanggal 2 Maret 2015. Tersedia: Roger $\mathrm{Hu}$ $\mathrm{P} 1-\mathrm{C} 02-1$ $<$ [Vincent_Ruggiero]_Beyon_Feelings_A_Guide_to_Critical Thinking.Pdf >

Sumarno, U. 2010. Berpikir dan disposisi matematika: apa, mengapa, dan bagaimana dikembangkan pada peserta didik. Diambil tanggal 27 Desembar 2014 dari http://www.berpikir-dan-disposisi-matematik-sps-2010.pdf

Uden, Lorna \& Beaumont, Chris. 2006. Technology and problem-based learning. London: Information Science Publishing (an imprint of Idea Group Inc.)

Weissinger, P.A., 2004. Critical thinking, metacognition, and problem-based learning,in enhancing thinking through problem-based learning approaches. Singapore: Thomson Learning.

Westwood. 2008. What teachers need to know about. Victoria, Australia: ACER press. 